\title{
PUBLIC MANAGEMENT OF INNOVATIONS IN THE SOCIO-HUMANITARIAN SPHERE: CHALLENGES AND WAYS TO OVERCOME
}

\author{
Andrii Moisiiakha ${ }^{1}$
}

Received: 2021-03-03

Accepted: 2021-04-20

DOI: http://doi.org/10.46489/gpj.2021-1-1-10

\begin{abstract}
EU integration and globalization trends require new mechanisms and methods of regulating economic processes to transform Ukraine into an economically developed powerful state. Innovation is an integral part of any production cycle, but to achieve better results, innovation processes and relationships in the creation and implementation of innovative technologies in the national economy require active participation and great attention from the state. The main emphasis of such attention should be focused on organizational, legal and institutional support of innovation, which requires solving a vast number of problems of intensive development. The end of the twentieth century was a period of spreading ideas about the need to change the paradigm of public administration. Scientists began to realize the need to move to a new model of public administration based on strengthening the social nature of government. The change in approach implies an essential change in the state's role: from the producer of public goods to the regulator of market processes. During the implementation of this model, the most crucial effect is possible if the principles of openness, innovation, decentralization, and a combination of market and state regulation, individual freedom and new forms of individual and collective responsibility.
\end{abstract}

Keywords: public administration, innovation sphere, innovative development, challenges.

\footnotetext{
${ }^{1}$ Andrii Moisiiakha, graduate student of the Department of Public Administration, Interregional Academy of Personnel Management, Frometivska str., 2, 03039 Kyiv, Ukraine, ORCID: https://orcid.org/0000-0002-7249$\underline{9272}$
} 


\section{ВСТУП}

Інноваційна діяльність в Україні завжди була одним із ключових об'єктів уваги держави. Вдосконалення державної політики в сфері інноваційного розвитку відбувається надзвичайно важко в силу наявності об'єктивних факторів та проблем розвитку інноваційної діяльності в Україні, які потребують нових прогресивних підходів до їх вирішення. Інновації передбачають ризик i прийняття потенціалу невдачі. Таким чином, звітність перед нашою державною адміністративною системою, процес інновацій зазвичай не асоціюється 3 мисленням та діями у державному секторі. Це справжній виклик, i якщо цей виклик буде подолано, інновації мають відповідні внутрішні канали для набуття чинності. Інновації - це динамічний процес, який змінює загальну архітектуру уряду, визначає проблеми, виклики, розробляє нові процеси, креатив, а також відбирає та впроваджує нові рішення. Таким чином, загалом риси інновацій багато в чому збігаються 3 процесом реформ. Важливим чинником просування інновацій $\epsilon$ просування творчого мислення. Інноваційний процес має важливе значення для підвищення ефективності державного сектору та надання якісних та конкурентоспроможних державних послуг.

Актуальність дослідження зумовлена обумовлена тим, що сучасний стан розвитку України ознаменувався рушійними трансформаціями системі світоглядних орієнтирах та цивілізаційних принципах розвитку українського суспільства. Приймаючи демократію, не як номінальну систему державних гарантій, а як реальний спосіб побудови соціо-економічних процесів Українська держава формує новий концепт громадянського суспільства, правової та соціально орієнтованої держави. За таких умов вектор соціально-гуманітарного розвитку набуває нового змісту та визначення свого місця в майбутньому України - формування потужного суспільства з високим рівнем правової культури, високою якістю життя, високими стандартами соціального забезпечення. Все це можливе через розробку ефективних механізмів державного управління розвитком гуманітарної, соціальної сфери, як окремих площ владно-управлінських відносин. Складність дослідження уявляється в тому, як саме визначити межі та зміст соціогуманітарної сфери, і саме в цьому вбачається найбільша актуальність роботи одночасно визначити нове наповнення та нове значення соціогуманітарної сфери для потреб процесів державотворення.

Існує усталена точка зору стосовно того, що державне управління в соціогуманітарній сфері повинно відбуватися в межах соціальної або гуманітарної політики, але на наше переконання потреби державного управління в цій сфері $\epsilon$ значно ширшими, оскільки вони пов'язані із формуванням соціальної та індивідуальної правосвідомості, національної ідеї через задоволення соціальних та гуманітарних потреб громадян, підвищення їх рівня життя та рівня соціального забезпечення.

Разом з тим, потребує вирішення питання щодо інституційного забезпечення державної політики у соціогуманітарній сфері. Справа в тому, що механізми державного регулювання $\epsilon$ рушійними елементами системи державно-владних відносин, в яких державні інституції виступають суб'єктами управління, а відносини в соціогуманітарній сфері - об’єктами. I саме для того, щоб максимізувати ефективність державного управління необхідна визначеність стосовно суб'єктної співвідносності механізмів державного регулювання зазначеною 
сферою зрозуміло, що державна політики у соціогуманітарній сфері генерується Кабінетом Міністрів України та Верховною Радою України, однак при визначенні механізмів такого регулювання, акценти уваги зміщуються в бік конкретних суб'єктів правозастосування та право регулювання засобами галузевих та локальних нормативно-правових актів. Невизначеність питання із суб'єктним складом системи державного регулювання відносини в соціогуманітарній сфері додатково підвищує актуальність дисертаційного дослідження.

Питанням державного регулювання інноваційної сфери присвячено роботи багатьох дослідників, серед яких Bekkers, V., J. Edelenbos \& B. Steijn (2011), Blunt, P. (2002), Caldwell, R. (2006), Cooke, P., Schwartz, D. (2007), Osborne, F. (2015), Van Gyes, G., Vandenbrande, T. (2005) та інші.

Адміністративні реформатори, які писали в першій половині XX століття, дискредитували поширення адміністративних цінностей. Державна політика шукає інновації як вирішення великих проблем суспільства, інновації $\epsilon$ імперативом державної політики: за часів обмеженості ресурсів урядів, інновації державних послуг стали обов'язковою умовою не відставання від потреб суспільства (Осборн, 2015). Інновація - поняття, що широко використовується, але невловиме. Визначення цього терміну часто $\epsilon$ циркулярними або ad hoc i рідко виходять за рамки здорового глузду розуміння використання чогось нового, як теоретизував у своїй книзі. $\mathrm{y}$ спеціальній літературі, яка ставить під сумнів питання сталого розвитку, «інновації» можуть сприймати моральні нюанси, часто подані з точки зору того, що «їм» потрібно робити, щоб стати обережнішим та поінформованим, та / або бути більш зосередженим на клієнті. Усі визнання, визначені для проведення цього дослідження, не свідчать про те, що інновації повинні бути радикальними або що вони з'являються виключно для продуктів. Ніщо не говорить про те, що інновації виняткові лише для великих організацій або окремих підприємців. У контексті організаційних інновацій це може статися у випадку продуктів, процесів чи послуг. Це може бути поступовим або радикальним, і це може відбуватися на різних рівнях в організації, починаючи від управлінських груп та підрозділів, закінчуючи командами дизайнерів i навіть окремими особами.

Інновації (та інновації в сфері послуг) традиційно розглядалися як засіб стимулювання зростання завдяки сукупному та орієнтованому на майбутнє процесу, що стосується організаційних інновацій, а також ринку чи презентації інновації, Van Geyes \& Vandenbrande (2005). Шукаючи джерела зростання, економісти зосередили свої зусилля на технологічних та наукових інноваціях, особливо починаючи з 1980 $\mathrm{x}$ років. Відповідно до цього, критерії визначення інновацій в основному стосувалися маркетингу або інтеграції нових розробок (компонента чи методу) у виробництво, а також технологічних продуктів та процесів у бізнесі / компаніях (наприклад Посібник Фраскаті, розроблений OCDE, та Посібник Осло, розроблений Євростатом). У той час, як сучасна економіка стає все більш орієнтованою на обслуговування, як повторив Гедрі, питання інновацій та ролі технологій 3 точки зору економічного зростання, починаючи 31990 р., Поставили економісти та соціологи в іншому світлі (Gadrey, 2003).

Незважаючи на поступовий процес гармонізації на основі Посібника з Осло, національні опитування щодо інновацій все ще мають деякі суттєві відмінності в методології та дизайні. Щодо форм оцінки, то вони включають послідовність та формулювання 
запитань, типи змінних (наприклад, категоричні проти числових), фільтрацію компаній на основі опитувальника тощо. Щодо дизайну та методології опитування, то він включає вибір цільової сукупності протягом звітного періоду, методи збору та обробки даних тощо.

\section{РЕЗУЛЬТАТИ}

Поняття “інноваційний розвиток”, “інновація" певним чином пов'язане 3 поняттям "ризик", що впливає на методологію розробки будь -якого управлінського рішення, що стосується інноваційного розвитку національних інноваційних систем. Зростання кількості банкрутств різних типів кризових ситуацій у сфері інновацій стало звичною рисою сьогодення. Тому перше місце посіла проблема прогнозування кризових подій, подій, ситуацій, пошуку напрямків ї̈ вирішення, формування профілактичних заходів щодо їх запобігання та подолання, підвищення ефективності та результативності стратегічного управління інноваційним розвитком національних інновацій системи в цілому. У таких випадках час гнучкий, чутливий до змін зовнішнього середовища, організаційної структури державного управління. В управлінні інноваційним розвитком національних інноваційних систем в основному зосереджується вирішення питань, пов'язаних 3 непередбачуваністю, відсутністю чіткого делегування повноважень, розподілом функцій між учасниками інноваційного процесу національними інноваційними системами в довгостроковій перспективі. Важливою особливістю управління інноваційним розвитком національних інноваційних систем $\epsilon$ забезпечення усунення перешкод для інноваційного розвитку 3 метою уникнення загроз та кризових ситуацій у діяльності суб'єктів національних інноваційних систем. Управління, що усуває перешкоди для інноваційного розвитку, - це сукупність форм і методів реалізації адміністративних процедур не лише стосовно конкретного інноваційного проекту, а й інноваційної діяльності суб'єктів національних інноваційних систем в цілому з метою усунення загроз та перешкод для інноваційний розвиток.

Часто дискусії щодо реформи державного управління викликають деяку плутанину щодо значення цієї фрази. Зокрема, реформа означає більше, ніж покращення адміністративної спроможності, про яку говорили, а щодо процесу інновацій $\epsilon$ звіт про включення. Коротка відповідь полягає в тому, що це дві різні концепції організації державного сектору. Реформа державного управління - це широке поняття, яке включає всі аспекти організації державного сектору, включаючи загальну характеристику міністерств та відомств, організацій, систем, структур, процесів, мотивацій, i те, як вони контролюються та реформуються в системі періодично, ми можемо спостерігати тут ми зробили відмінність на формальному рівні, подібну до того, як класифікуються інновації. 3 одного боку, адміністрація відноситься до способу координації діяльності у державному секторі, вона формально уповноважена, розпоряджена та організована; з іншого боку, адміністративне нововведення, яке не аналізується та не розглядається на загальному рівні, $\epsilon$ процесом, який впроваджується на галузевому рівні, так що характеристика конкретного сектора також визначає, як інновації набувають своєї форми. у цьому випадку ми можемо розглядати процес інновацій як лише одну 3 реформ державного управління. Однак адміністративна інновація $\epsilon$ важливою для процесу реформування та функціонування та розвитку держави, але, як ми бачили, є лише частиною цього бачення, і сама по собі не може дати результатів, очікуваних від 
сучасної адміністрації. Насправді, просто збільшення рівня інновацій на галузевому рівні може призвести до розбіжностей у отриманні результатів, оскільки це частково залежить від того, як вони організовані та проведені, і від того, як це включено до всіх функціональних підрозділів адміністрації.

Громадський характер розвитку має значну кількість проблем. Так, основними проблемами слід вважати:

1. Проблема нормативнометодологічного характеру. Мова йде про системну недосконалість та невпорядкованість законодавства в сфері інновацій. Тривалий час інноваційному законодавству України була властива певна фрагментарність та непослідовність. У загальному вигляді законодавчі та нормативно-правові акти з інноваційної діяльності, що були прийняті в останні роки, можна об'єднати у три основні групи, які регулюють такі питання: внутрішньоекономічні відносини щодо інноваційного розвитку, здійснення інноваційної діяльності в різних сферах господарської; особливості здійснення інноваційної діяльності в межах окремих інноваційних структур; питання інтелектуальної власності і механізм інформаційного забезпечення інноваційної діяльності. Однак вже навіть таке групування нормативноправових актів засвідчує той факт, що інноваційне законодавство формується за рахунок величезного масиву законодавчих та підзаконних нормативно-правових актів, які інколи не те що навіть не співвідносяться, але суперечать одне одному. В такій кількості окремих актів відсутня навіть сама логіка законодавчого регулювання в аспекті єдиної стратегічної мети державної інноваційної політики.

В цьому контексті варто звернути увагу на необхідності гармонізації положень законодавчих та нормативних актів i, насамперед, законів України
«Про наукову і науково-технічну діяльність» «Про інноваційну діяльність», «Про пріоритети інноваційної діяльності в Україні», «Про спеціальний режим інноваційноінвестиційної діяльності технопарків» тощо».

Рекомендації Світового банку акцентують увагу на необхідності деталізації окремих законодавчих актів, зокрема в сферах діяльності технопаркових структур; академічного підприємництва 3 акцентом на капіталізацію інтелектуального капіталу; розвитку інноваційних агенцій та інших інфраструктурних елементів. Фахівці Світового банку вважають, що реформа державного управління інноваційній сфері повинна бути широкою i вийти за рамки звичайних правових актів в сфері регулювання інноваційної діяльності та діяльності технопарків. Вона повинна охоплювати трудові та податкові правові акти, реалізація яких впливає на успішну політику в області інтелектуальної власності та трансферту технологій.

Однак, на наше стійке переконання більшість механізмів, зокрема державної фінансової підтримки та стимулювання, пільгового оподаткування інноваційної діяльності, стимулів для суб'єктів відносин 3 приводу трансферту технологій не можуть ефективно забезпечуватися наявною архітектонікою нормативноправового регулювання інноваційної діяльності. Натомість на нашу думку існує необхідність грунтовної систематизації інноваційного законодавства шляхом його кодифікації та розробки Інноваційного кодексу України. Мова не йде про доктринізації інноваційного права, а лише про об'єднання нормативно-правових актів, які регулюються інноваційну діяльність в окремий кодифікований акт, в якому будуть визначені основні засади державно-правового регулювання 
інноваційної

діяльності, встановлюватимуться стандарти та норми функціонування інноваційних підприємства та інфраструктури ринку інновацій, визначатимуться державні гарантії та межі втручання органів державної влади в процеси інноваційного відтворення.

2. Другою проблемою, що заважає ефективному регулювання інноваційної діяльності і досить тісно пов'язана із проблемою неефективності законодавчого регулювання відсутність механізмів забезпечення та підтримки привабливого інвестиційного клімату в сфері інновацій. В цьому контексті необхідно звернути увагу на відсутності єдиного комплексного бачення законодавцем та урядом механізму взаємодії інноваційного сектору з промисловістю. На сьогодні концепція державного регулювання інноваційної сфери тяжіє до визнання інновації як окремого продукту та спробам врегулювати відносини 3 приводу іï створення, поширення, трансферта, ринкового обігу. Інновація повинна створюватися для задоволення не кон'юнктурних, а стратегічних потреб промислового сектору, а тому промислові підприємства повинні бути тими визначальними суб'єктами, які формують попит на інновації в довгостроковій перспективі. 3 цих позицій вбачається логічним, що держава акцентує свою увагу на формуванні стійких взаємозв'язків між інтелектуальним та промисловим потенціалами шляхом створення умов для інтеграції науки в виробничу сферу.

Таким чином, формуватиметься належний та сприятливий інвестиційний клімат, оскільки інвестори будуть чітко розуміти утилітарність інновацій, ї пристосованість до вимог майбутнього, а не сьогодення. Це означатиме розвиток венчурного бізнесу, але створюватиме стійки та розгалужені мережеві структури де центр генерації інновацій буде одночасно центром всієї промислово-виробничої структури. Тобто інноваційне виробництво означатиме такий рівень задоволення потреб промисловості в інноваціях, за якого інноваційні технології будуть постійно та систематично впроваджуватися в практичну діяльність суб'єктів господарювання. Фактично відбуватиметься процес постійного ресайклінгу, який дасть змогу суттєво збільшити пропозицію об'єктів інвестування для потенційних інвесторів. Більше того такий безперервний процес практичного впровадження інновацій створить передумови для гарантованого стійкого отримання прибутку від інвестицій.

Зусилля держави в цьому контексті повинні концентруватися навколо організаційно-правового та інституційного забезпечення зрощення інноваційних центрів та суб'єктів інноваційної діяльності із суб'єктами господарювання шляхом інтеграції перших в мережеве структурне утворення - кластер.

3. Наступною проблемою слід вважати нестачу елементів інфраструктури інноваційного сектору. Сутність цієї проблеми полягає в тому, що для забезпечення сталих темпів зростання економіки країни на інноваційній основі необхідним $\epsilon$ існування суб'єктів, які напряму не створюють інновації, але активізують інноваційну діяльність.

Насправді, оптимальним варіантом розвитку інноваційної складової в економіці країни буде створення мережі технопарків та територіальних центрів («полісів») зростання, сприяючих залученню приватного бізнесу у фінансування науково-дослідних розробок і процесу впровадження нових технологій у виробництво. Хоча самі по собі технопарки не $€$ генераторами інновацій, вони лише створюють середовище для їх генерування 
окремими

науково-дослідними

інститутами або центрами.

Специфічними інфраструктурними інституціями $\epsilon$ інноваційні агентства. Їх місія полягає в постійному моніторингу процесів інноваційного розвитку, а також попиту на інновації з тим, щоби корегувати фінансові потоки спрямовані державою на розвиток тих и інших інновацій. Разом 3 тим слід розуміти, що творення інноваційних агентств передбачає об'єктивну необхідність наділення їх широкою автономією у питаннях корегування інноваційних процесів в реальному секторі виходячи із потреб промислового розвитку та пріоритетів національної економічної політики.

Більше того, розвиток мережі інноваційних агентств на наш погляд дозволить вирішити ще одну важливу проблему - оптимізацію фінансування НДДКР за рахунок державних коштів. Так чи інакше, але сучасна вітчизняна промисловість залежить від державного фінансування НДДКР, оскільки самі суб'єкти господарювання не здатні в своїй більшості за власний рахунок оновлювати основні фонди.

Саме інноваційні агентства, здатні вирішити проблему організації системи прогнозування і планування підготовки кадрів для інноваційних та наукових організацій на середньострокову i довгострокову перспективи. Це дозволить об'єднати зусилля академічної, вузівської і галузевої науки з метою підвищення конкурентоспроможності продукції національної на основі інтенсифікації інноваційної діяльності. Єдиною важливою умовою практичної реалізації означеного напрямку $\epsilon$ наділення цих агентств таким рівнем повноважень та таким обсягом функцій, які б в повній мірі забезпечували координацію та систем академічної, вузівської та галузевої науки.
Також, визначальним аспектом функціонування інноваційних агентств слід вважати їх участь в процесі укладання угод щодо проведення спільних досліджень та реалізації інноваційних проектів між різними суб'єктами інноваційної діяльності. Такі угоди можуть укладатися як в межах кластеру, технопарку або технополісу, так і між розрізненими суб'єктами інноваційної діяльності 3 метою підвищення рівня кооперації ресурсів та інтелектуального капіталу.

4. Наступна проблема розвитку державного регулювання в інноваційній сфері полягає у недосконалому інституційному забезпеченню такого регулювання. Сучасна модель державного регулювання створена на засадах процесного підходу, коли регулювання інноваційної діяльності відбувається тими державними інституціями, в сферу регулювання яких входять процесні відносини між суб'єктами інноваційної діяльності. Підвищення ефективності інституційного забезпечення державної політики в інноваційній сфері передбачається за рахунок організації моделі державного регулювання заснованої на цільовому підході.

Таким чином, пропонується централізувати процеси управління інноваційною екосистемою шляхом залучення низки координуючих та контролюючих органів: Пажи 3 розвитку інновацій, Офісу з розвитку інновацій, Національного фонду досліджень, Українського національного фонду стартапів - що суттєво підвищить ефективність визначення пріоритетів державної інноваційної політики, а також оптимальність використання державного фіннасування через пряму підтримку НДДКР та стартапів.

При цьому традиційно розробляти основні засади державної інноваційної політики будуть міністерства та відомства - центральні органи 
виконавчої влади, але фактично на рівні практичної реалізації такої політики створюватимуться нові ефективні державні структури. Наведена модель дасть змогу суттєво підвищити ефективність функціонального розподілу та сконцентрує моніторингові і контрольні функції, що забезпечить мобільність i оперативність прийняття рішень в процесі корегування державного управління розвитку інноваційної діяльності.

Процес управління усуненням бар'єрів для інноваційного розвитку передбачає виділення його елементів (Kelley, 2016, 43):

- аналіз стану макро- та мікросередовища та вибір найкращих агентів місії $\mathrm{y}$ національних інноваційних системах;

- розкриття заходів управління економічними заходами 3 метою виявлення перешкод на шляху інноваційного розвитку, формування системи моніторингу суб'єктів навколишнього середовища у національних інноваційних системах 3 метою раннього виявлення слабких сигналів в інноваційній діяльності;

- стратегічний контроль інноваційної діяльності суб'єктів національних інноваційних систем та розвиток діяльності запобігання втручанням у інноваційний розвиток;

- оперативна оцінка та аналіз фінансового стану суб'єктів національних інноваційних систем 3 метою виявлення можливості колапсу в інноваційному процесі;

- політика розвитку в умовах згортання інноваційного процесу та

\section{References}

Bekkers, V., J. Edelenbos \& B. Steijn (2011). An Innovative Public Sector? виведення суб'єктів національних інноваційних систем цієї держави;

- постійний ризик інноваційної діяльності та розробка заходів щодо іiї скорочення.

Основним завданням обмежень площини управління для інноваційного розвитку $\epsilon$ розробка та прийняття адміністративних рішень 3 мінімальним ризиком та додатковими ресурсами, 3 мінімальними негативними наслідками для досягнення поставлених цілей та очікуваних результатів. Реалізація цього завдання передбачає такі завдання управління усуненням перешкод для інноваційного розвитку:

- діагностика та оцінка параметрів виникнення перешкод;

- розробка концепції та відповідного комплексу заходів щодо подолання бар'єрів шляхом здійснення відповідних стратегічних та оперативних дій;

- реалізація цієї концепції в процесі усунення перешкод;

- постійний моніторинг зовнішніх та внутрішніх факторів процесу усунення безладу.

\section{ВИСНОВКИ}

Підводячи підсумки слід зазначити, що найбільш актуальними проблемами сучасного стан розвитку державного регулювання інноваційної сфер $\epsilon$ проблеми пов'язані із системними недоліками вітчизняної державноуправлінської парадигми в цілому. Запропоновані напрямки вирішення цих проблем відкривають нові можливості для інтенсивного розвитку інноваційної сфери та швидкої адаптації інноваційних продуктів в промисловому секторі, що в свою чергу підвищуватиме якість інноваційної складової національної економіки.

Embarking on the Innovation Journey, in: Bekkers, V., J. Edelenbos \& B. Steijn (eds.), Innovation in the public sector: linking 
capacity and leadership. Houndsmills: Palgrave McMillan; 197-222.

Blunt, P. (2002). Public Administrative Reform and Management Innovation for Developing Countries: UNDP, pp. 2.

Caldwell, R (2006). Agency and change: rethinking change agency in organizations. Routledge, London.

Cooke, P., Schwartz, D. (eds) (2007). Creative Regions. Technology, culture and Knowledge Entrepreneurship. London and New York: Routledge

Kelley, C.S. (2016). Presidential Signing Statements and Public Administration. In A. Farazmand (Ed.), Global Encyclopedia of Public Administration, Public Policy, and Governance. Cham: Springer International Publishing.

Osborne, F. (2015). An integrated framework for risk governance. Society and Economy 37 (2). 165-182

Van Gyes, G., Vandenbrande, T. (2005) Innovation and labour issues. A literature study of policy uncertainties from the Flemish point of view. Leuven: Higher Institute for Labour 